\title{
Strengthening the ecological security of Poland on the example of initiatives limiting the phenomenon of smog
}

\author{
Wzmocnienie bezpieczeństwa ekologicznego Polski \\ na przykładzie działań ograniczających zjawisko smogu
}

\author{
Michał Czuba*
}

\begin{abstract}
Humans and their existence depend on the natural system. Maintaining balance in this system requires proper management of natural resources and taking actions aimed at limiting and preventing negative effects of the economic activity as well as rational use of natural resources available in a given time. The effects of the intensive development of the economy with the uncontrolled use of natural resources were felt by developed countries already in the first, and much stronger in the second half of the 20 th century. One of them is air pollution contributing to the formation of smog. This problem is so important in Polish conditions that measures are taken by the government and its authorities to limit the effects and scope of this phenomenon. These activities serve to increase the ecological security.
\end{abstract}

\begin{abstract}
Abstrakt
Człowiek i jego egzystencja jest uzależniona od systemu przyrodniczego. Zachowanie równowagi w tym systemie wymaga właściwego zarządzania zasobami naturalnymi oraz podejmowania działań zmierzających do ograniczenia i zapobiegania negatywnym skutkom działalności gospodarczej a także racjonalnego wykorzystania dostępnych w określonym czasie zasobów przyrodniczych. Skutki intensywnego rozwoju gospodarki przy niekontrolowanym korzystaniu z zasobów naturalnych odczuły kraje wysoko rozwinięte już w pierwszej, a znacznie mocniej w drugiej połowie XX wieku. Jednym z nich jest zanieczyszczenie powietrza przyczyniające się do powstawania smogu. Problem ten jest na tyle istotny w warunkach polskich, że podejmowane są przez rząd i jego organy działania służące
\end{abstract}

* Institute of Political Science, University of Silesia in Katowice (phdmuczba@o2.pl); https://orcid.org/0000-0001-6018-3484. 
Over the past dozen or so years, there has been a significant evolution of environmental policy in Poland, new regulations have been created in the field of environmental law. The paper analyzes the issues of Poland's environmental policy up to 2030 and the "Clean Air" program implemented under this policy. It also attempts to indicate the positive social effects resulting from its implementation.

Keywords: ecological policy, ecological security, smog, governmental program ograniczeniu skutków i zasięgu tego zjawiska. Działania te służą zwiększeniu bezpieczeństwa ekologicznego.

W ciągu ostatnich kilkunastu lat nastąpiła znaczna ewolucja polityki ekologicznej prowadzonej w Polsce, powstały nowe regulacje w zakresie prawa ochrony środowiska. Powyższy artykuł analizuje kwestie polityki ekologicznej Polski do roku 2030 i realizowany w jej ramach program 'Czyste powietrze '.Próbuje on także wskazać pozytywne skutki społeczne wynikające z jego realizacji.

Słowa kluczowe: polityka ekologiczna, bezpieczeństwo ekologiczne, smog, program rządowy

\section{Introduction}

The appropriate state of the natural environment is an element conditioning the life of urban residents. In Polish conditions, the smog is the problem of many cities, which has a negative impact on human health. Therefore, measures are taken to limit the scale of this phenomenon. They are inscribed in the current ecological policy of Poland and expressed in specific activities of Polish municipalities in this area. This paper attempts to present an outline of Poland's environmental policy until 2030 with its references to the issue of air pollution. It presents the assumption of the "Clean Air" program currently being implemented by the Polish government.

The theoretical aim of this paper is to visualize the political perspective in the field of environmental protection. Its cognitive goal is to present the scope of Poland's environmental policy until 2030 and the "Clean Air" program that is being currently implemented by the government, while the utilitarian purpose is to try to identify positive social effects related to the above-mentioned program accompanying the issue of air pollution.

Referring to methodological issues, it should be stated that political and administrative sciences use research methods which belong to social sciences and humanities. Therefore, they use to a large extent the examination of documents (e.g., legal acts), comparative methods (expert opinions, legal opinions, analyzes resulting from linguistic, grammatical and historical interpretation) and case studies (cases). As the basic research method, the paper adopted the method of document examination and expert opinions related to the issues raised in this 
publication. Induction was used as the main inference method for the purposes of this study. It consists in deriving general conclusions or establishing regularities based on the analysis of empirically confirmed phenomena and processes. It is based on inference founded on the details of the general properties of a phenomenon or object. The application of this method rests on the belief that only observable facts can form the basis of scientific inference. These facts are real situations (e.g., economic and legal).

\section{Ecological security - essence of the issue}

Climate changes that have occurred in recent years set a new style of thinking. They cause negative consequences that may affect people and the environment. The ecological safety category has different perspectives.

First, ecological security is related to protection and use of the most important basis, the origin of human living - external environment, which does not have any administrative, national, or state borders. Second, solving the problems of ecology and providing ecological security is an important and necessary precondition for solving economic, social, political, and other problems of the state. Third, ecological crisis can be much more dangerous - as to its scale and consequences - than, for example, political, military, economic, financial crunch. Fourth, multidimensionality, complexity, large scale, and depth of ecological problems make ecological security one of the most important issues in modern conditions of the development of state (Skiter, Rogachev, Mazeva, 2015).

There is no single definition reflecting the sense term "ecological security." Some definitions treat ecological security as a state of protection of human, society, and environment from harmful influences of anthropogenous factors, natural hazards, and catastrophes(Taylor, 2014). Others describe ecological security as an element of environmental protection (Xie, 2014). Still others equate ecological security and environmental protection (Bucagu, Vanlauwe, Wijk, Giller, 2014). There are also those who use the notion of "ecological security" to denote not only environmental protection but also rational use of natural resources, their reproduction, and quality improvement (Yin, Xu, Chen, Wu, 2014).

According to S. Śladkowski, ecological security can be considered a state of counteracting social effects of transformations of the surrounding environment. An analogical definition characterizes ecological safety as a condition of an ecosystem in which the risk of disturbances of its components is small( Sladkowski, 2004).

Ecological security can also be understood as a balance between humans and the earth. All threats that are possible to occur should be analyzed from an 
ecological perspective because each of them will have a negative impact on the environment, which is also created by human beings (Górska-Rożej, 2013).

Ecological security is related to the social perspective. J. Kukułka claims that society can prevent deficiencies that arise in the environment and the harmful changes that occur in it. Developing this approach, it can be said that ecological threats are created by humans who threaten the environment with their actions, sometimes unconscious and ill-conceived. As a consequence, they also threaten themselves because they are forced to exist in a failing ecosystem, thus destroying peace and safety (Kukułka, 1995).

Ecological security in the common understanding is treated as a permanent and unsanctioned process that leads to the desired ecological state, while protecting the healthy and peaceful existence of all components of the ecosystem, using measures in accordance with the principles of internal coexistence of the state and international society (Geneza bezpieczeństwa ekologicznego).

The lack of ecological security results from the existence of threats that may occur individually or collectively, to engage and to induce interactions.

To analyze the environmental hazards, it is necessary to locate their causes. In this respects, hazards of a subjective and objective nature can be distinguished (Śladkowski, 2004).

Subjective hazards - are the result of actions that by changing the natural relationship of a human to biocenoses and biotopes, which can lead to the population being destroyed.

Their sources are mainly:

- breakdown of natural balance as a consequence of excessive exploitation of environmental resources,

- pollution of the spheres of land and the environment by substances of industrial, transport and municipal origin,

- progressive degradation of ecosystems due to pollution of toxic waste and ecological disasters.

The subjective threats are the result of events caused by natural forces and economic activity perceived as:

- natural - consequences of natural disasters and catastrophes,

- civilizational - material pollution of various types and kinds introduced into the environment in the course of human activity (Kłodziński, 2008).

The threats mentioned violate ecological security. Concerning the issue of smog and air pollution, the subjective threats of the industrial, transport and municipal origin as well as subjective threats, especially the civilizational threats, are of significant importance.

Nowadays the whole world is tracking the information about subsequent COVID-19 incidents with increasing concern. In addition to health issues, the economic consequences of its prolonged duration will be of particular concern.

The impact of a coronavirus pandemic on the state of the environment can be considered positive. Reducing economic activity, air and car transport sig- 
nificantly reduced the negative impact of human activities on the natural environment. This fact is confirmed by satellite images taken in China in December 2019 and February 2020. Especially in this second period, China was basically a clean state, which is not a common phenomenon for them (Walka o środowisko... 2020).

Coronavirus has had a positive effect on the environment. Its effect is to reduce greenhouse gas emissions and return animals to their natural habitats. The isolation order for citizens has resulted in significantly lower emissions of dust and harmful greenhouse gases (especially $\mathrm{NO} 2$ and $\mathrm{CO} 2$ ) in Europe. Nitrogen dioxide amount decreased over Italy and New York. This trend is visible in virtually all pandemic countries. The same applies to carbon dioxide (Tollefson, 2020).

\section{Ecological issues in the political science}

The changes that took place in the 20th century caused that the issue of environmental protection gained importance, not only in the social context but also in a political perspective. In this dimension, the care for the environment became the subject of politics and the problem of biological survival, among others, of the human species emerged. The result of this approach was the creation of a pro-ecological social movement, which in many countries adopted the institutional form - a party with a pro-ecological attitude. In addition, environmental protection and the accompanying so-called green policy has become one of the three foundations for sustainable development since the middle of the last century (outside the economic and social sphere). Caring for the natural environment has become a sphere that should be taken into account when making political, social and economic decisions.

Nowadays, in the field of political science, there are at least two approaches to the problem of environmental protection in building political capital — program and declarative. The program approach treats ecology as one of the essential components of party and electoral programs, and at the same time, an important area of state activity. This approach is consistent with international policy, where environmental protection becomes one of the most important public issues. The declarative approach treats environmental policy as actions aimed at exercising power and as an area to reconcile particular group interests. In this sense, environmental policy can be part of a political game that leads to the perception of environmental protection as a component of short-term political or electoral alliances in order to build or enlarge political capital (Gamczewska et al., 2017).

The second half of the $20^{\text {th }}$ century is also the time of the emergence of proenvironmental movements in Europe and North America. In the political thought 
up to the second half of the $20^{\text {th }}$ century, the anthropocentric approach became apparent. According to it, a human being was the central element of all ideas and considerations. Along with the transformations initiated by the industrial revolution and its consequences for the environment that came with it, the slogans of ecocentrism appeared as a holistic approach to social reality. According to this concept, an individual and society are an element of a larger system and at the same time constitute the greatest threat to its functioning. Intense economic development causes degradation of the natural environment. The basic factors that disrupt them are: excessive exploitation of non-renewable natural resources, pollution of the atmosphere with industrial gases or industrialization. The ideas presented constitute a broad current of contemporary political thought, combining a broad current of contemporary political thought, combining the issues of environmental protection with the slogans of other philosophical orientations. Ecopolitics combines the assumptions of other ideologies: socialist, liberal, feminist and anarchist, based on four basic areas: ecological responsibility, social justice, democracy and pacifism. The main assumption of environmentalism is to prevent the destruction of the natural environment by means of tools that counteract excessive growth of the economic development rate and put nature above the individual's needs (Heywood, 2007). The pro-ecological ideas very quickly began to be represented institutionally by the associations, followed by political parties.

In addition to the issues outlined, political scientists are interested in the issues of international, regional and national environmental policy. They conduct and analyze facts about the activities of the United Nations, the European Union, individual states, and inter-state cooperation for the protection of the environment. They note all resolutions, conventions and statements of prominent politicians for this purpose. They explore the issue of the place of environmental protection in the activities of individual state authorities, in the programs and activities of political parties, movements and social organizations. They study the relationship between the strength and activity of non-governmental ecological organizations and the development of civil society. They characterize the activities of environmental leaders. They undertake theoretical issues such as sustainable development, ecological safety, and environmental policy instruments (Papuziński, 2006).

\section{The problem of smog in Poland}

For many years of the 20th century, the concentration of air pollutants remained in Poland - mainly in the Upper Silesia and other heavily industrial- 
ized areas - on a permanent and high level. The political, economic and social change after 1989 - the collapse of industries, closure of factories, plants and mines contributed to the systematic decrease in the level of air pollution which has remained at a similar level in Poland since the beginning of the 21st century. This is despite the fact that in other European Union countries the average emission of basic air pollutants is systematically decreasing (Kuchcik, Milewski, 2018).

Smog is made up of primary pollutants (dust, gases and vapors emitted by industrial plants, power plants, combustion engines of motor vehicles) and products of their photochemical and chemical transformations arising in the inversion of temperature under windless weather. Its creation is also facilitated by the location of areas threatened by it in depressions. Smog, due to the high concentration of aggressive chemical agents, poses a threat to human and animal health, causes plant diseases, and contributes to the destruction of materials" (PWN Encyclopedia.).

The phenomenon of smog is associated with a high concentration of PM10 suspended dust (dust with aerodynamic diameter of grains up to $10 \mu \mathrm{m}$ ) in the air and PM2,5 (dust with a particle aerodynamic diameter of up to $2.5 \mu \mathrm{m}$ ) (Regulation of the Ministry of Environment of September 13, 2012)

According to the European Environment Agency's Report, the most important problem of Europe for the sanitary state of air, understood as the overall composition of the atmosphere with admixtures in a given place and time, is the contamination with suspended dust (PM10 and PM2,5), tropospheric ozone $\left(\mathrm{O}_{3}\right)$ and nitrogen dioxide $\left(\mathrm{NO}_{2}\right)$, and nearly half a million people living in the EU die prematurely over the air pollution, of which over 47 thousand people a year in Poland (EEA, 2016, Air quality in Europe - report).

In recent years, air quality standards have been exceeded almost all over Poland. Exceeding standards for the concentration of suspended dust PM10 occur in $91 \%$ of measurement zones - especially in the Silesian, Lesser Poland and Lodz municipalities, with the exception of northern areas of the country. Exceeding norms for concentration of highly carcinogenic benzo(a)pyrene took place in all zones. In comparison with other EU countries, Poland ranks poorly in terms of air pollution with PM10 dust, finder dust PM2,5, as well as polycyclic aromatic hydrocarbons (including benzo(a)pyrene). The concentrations of PM10 and PM2.5 dust as well as benzo(a)pyrene registered in Poland are among the highest in the European Union (GIOŚ, 2014),.

Their most important sources are:

- low emissions, i.e., exhaust gases from boilers and solid fuel stoves in households;

- industry;

- road transport;

- energy. 


\section{Ecological policy of poland and its references to the smog phenomenon}

On February 14, 2017, the Council of Ministers adopted a new mediumterm strategy for the development of the country - the Strategy for Responsible Development until 2020 (with a prospect until 2030) - SOR. The objectives, directions of intervention, activities and strategic projects indicated in the SOR should be reflected in all strategic documents of Poland. Therefore, SOR is the basis for the preparation of new sectoral strategies, including the environmental strategy. Work on the environmental strategy was coordinated by the Ministry of the Environment with the support of members of the inter-ministerial team. The document was entitled the Ecological Policy of the State 2030 (PEP). It takes into account the problem of air pollution in Poland and its causes. The PEP assumptions include the references to the issue of air quality and the need to protect it.

The construction of an innovative economy while maintaining the principles of sustainable development is to be the priority of the new ecological policy of Poland, which is the requirement of the modern state policy. It is an individual who is the supreme value in the Ecological Policy of the State 2030 by drawing attention to such issues as the quality of life, health and well-being of the Poles. The role of ecological policy is to ensure the ecological safety of the state. This should be reflected in appropriate state management structures at the national, provincial and local levels. Furthermore, the division of competences and tasks should allow targets at each level to be determined based on the recognition of needs, and the means to achieve them are selected taking into account criteria for ecological and economic efficiency. The proper use of the environment at the local government level is crucial for achieving the environmental policy objectives, especially through rational planning of spatial development that helps protect the population from air pollution and noise and nature from excessive pressure of human activity.

The striving to improve the quality of life causes a constant need for development, which can only be achieved through the sustainable use of natural resources. None of the forms of human activity can cause permanent deterioration of the state of natural resources. Therefore, the development process will be monitored by means of appropriate indicators that enable the assessment of such aspects as: improvement of water and air quality, reduction of impact on climate change, and preservation of the full species composition of native fauna and flora.

Measures aimed at improving the air quality by limiting low emissions are to be implemented as part of the Environmental Policy of the State 2030. At the government level, they mean the preparation of appropriate regulations and fi- 
nancial support instruments for investments, as well as the coordination of their implementation in the regions.

In Poland, starting from 1990, the pollution of air, water and soil has been decreasing as a result of structural changes in the economy, the implementation of the state's environmental policy and its executive programs with pro-environmental investments and tightening of legal provisions,. Effective management of industrial emissions, especially in the energy sector, significantly reduced their share in exceeding air quality standards in Poland and allowed for a significant reduction of greenhouse gas emissions. However, effective climate protection requires further emission reduction, using the constantly improved technical and natural methods.

The most important challenges in this regard include the elimination of the so-called low emission, which is the result of the use solid fuels (including lowquality coal) and waste in the municipal-utility sector, most of all for individual heating of buildings, exploitation and technological maladjustment of heating stoves and small local boiler houses, as well as low energy standard of buildings. In urbanized areas and along commuting routes, a significant contribution of emissions from transport has a significant impact on air quality. Currently, regulations regarding car emission standards are adopted at the EU level, and actions in the field of electric transport are promoted at the national level (Polityka ekologiczna państwa 2030-projekt).

\section{Social benefits of the "clean air" governemnt program}

In September 2018, the government priority program "Clean Air" entered into force, which will last until 2029. Its most important goal is to reduce emissions of harmful substances to the atmosphere that arise from heating singlefamily houses with low-quality fuel in outdated domestic heating stoves.

The program makes it possible to obtain co-financing for exchanging old and inefficient heat sources for solid fuel with modern heat sources that meet the highest standards: heat distribution, heat pump, condensing gas boiler, condensing oil boiler, electric heating, solid fuel boiler (coal, biomass), as well as carrying out the necessary thermo-modernization works of the building.

The program provides for co-financing, among others, of:

- replacement of old heat sources (heating stoves and boilers for solid fuels) and purchase and installation of new heat sources that meet the program's requirements,

- insulation of building partitions,

- replacement of window and door joinery, 
- installation of renewable energy sources (solar collectors and photovoltaic installations),

- assembly of mechanical ventilation with heat recovery.

The government program being analyzed tries to limit the main reason for the problem of smog in our country, which is low emission, i.e., the release of harmful substances from domestic coal-fired stoves into the atmosphere. As it turns out, the exchange of the heating system itself is not enough. Without proper insulation of the house, all heat can quickly penetrate outside. Many houses in Poland were built in times when a solution with thermal insulation has not yet been applied, which leads to energy waste and large heat losses, as well as higher heating bills. That is why home thermo-modernization is so important, which will additionally affect savings in the home budget. Real estate insulation combined with replacement of windows allows the reduction of annual heating expenses by up to $40 \%$.

Currently, the owners or co-owners of a single-family residential building or an apartment separated in a single-family building with a separate land and mortgage register and persons who have obtained permission to start a singlefamily residential building and the building has not yet been handed over or declared for use are the addressees of the "Clean Air" program.

They can apply for subsidies or loans for the exchange of heat and works related to thermal-modernization. Participating in the program allowes for some of the costs incurred to be refunded. The maximum possible cost from which the subsidy is calculated is PLN53,000. The minimum eligible cost of the project is PLN7,000. Depending on the monthly income per person in the household, beneficiaries of the program will receive co-financing to cover up to 90 percent of eligible investment costs (O programie Czyste powietrze).

The "Clean Air" program implemented will ensure the achievement of social benefits, especially related to the health issues of our society. People who are most exposed to negative effects are children, also in the prenatal period, the elderly, as well as people suffering from cardiovascular and respiratory diseases, diabetes or obesity problems.

Every year, 40,000-45,000 people die in Poland due to complications caused by polluted air. The improvement of air quality in Poland may extend the average life expectancy of the Poles by 6-12 months. Improving the cleanliness of the environment and, above all, reducing dustiness and concentrations of harmful gases should translate into a decrease in diseases such as bronchial asthma, respiratory infections, tumours (of lungs, brain, bladder or even cervix), or cardiovascular and nervous system diseases.

Combating phenomena that cause smog can also contribute to the improved comfort of living in cities, especially in their centers. To this end, activities are currently carried out to limit the movement of motor vehicles in the city centers 
and are replaced by electric vehicles. These measures should also reduce noise levels, which in many city centers far exceed the permissible standards.

Limiting the phenomenon of smog, there would also be no need to close windows, leave the elderly, the sick and children at home, and people going to work or school would not have to put on uncomfortable masks with a filter. In addition, people who suffer from respiratory problems on days with smog often have to take larger amounts of medication or supplements to avoid breathing problems.

Investments financed under the "Clean Air" program contribute to the comfort of living. Its beneficiaries can increase it by replacing the heating stove with a modern one, with a feeder, which does not require frequent visits to the boiler room and gives more time to its owner, who can devote it to other matters (Strona internetowa Środowisko Życiem: Stop Smog).

\section{Conclusions}

This paper deals with the state's pro-ecological policy with regard to the issue of air cleanliness and the phenomenon of smog arising in Poland. It outlines the political perspective of these issues, translating into the environmental policy of the state. Analyzing the current ecological policy of Poland in the perspective of 2030, its assumptions and approach to shaping the natural environment in Poland coincides in large part with the assumption of the governing party's program approach to the environmental protection. It results from, to a large extent, Poland's membership in the European Union and the necessity for it to meet certain standards in the field of environmental protection, which arise from the directives of the European Commission and international conventions in this area. In order to meet these requirements, the "Clean Air" program is currently being implemented by the government. It makes it possible to obtain subsidies and loans for private individuals who want to make investments that limit the consumption of thermal energy and replace the existing coal stoves with modern heating devices that contribute to the reduction of air pollution. The analyzed program offers social benefits in the area of improving the health of the Poles and reducing the number of diseases caused by polluted air. It also contributes to the improvement of the quality of life of the Poles in cities by limiting the nuisance of closing windows due to smog, wearing anti-smog masks, the necessity of people with respiratory diseases to stay at home and using additional medicines, which also has a positive effect for this group of people. 


\section{References}

Bucagu C. , Vanlauwe B., Van Wijk, M.T. , Giller K.E.(2014).Resource use and food self-sufficiency at farm scale within two agroecological zones of Rwanda, Food Security, 6(5).2014, s. 609-628.

EEA( 2016). Air quality in Europe - 2016 report. Report No 28/2016, European Environment Agency,

Kopenhaga, Dania. z: www.eea.europa.eu/publications/air-quality-in-europe-2016

Encyklopedia PWN, Definicja pojęcia: smog. Pobrano z: www.encyklopedia.pwn.pl/ (data dostępu: 30.06.2019)

Garnczewska A.(red.).(2017).Współczesne problemy ekologiczne świata. Toruń: Kolegium Jagiellońskie - Toruńska Szkoła Wyższa

Geneza bezpieczeństwa ekologicznego. z: www.kpswjg.pl (20.12.2013)

GIOŚ(2014). Stan Środowiska w Polsce. Raport 2014, Biblioteka Monitoringu Środowiska, Warszawa. www.gios.gov.pl/images/dokumenty/pms/raporty/GIOS raport 2014.pdf. (23.06.2019)

Górska-Rożej K.(2013). Bezpieczeństwo ekologiczne w ogólnym systemie bezpieczeństwa państwa, Obronność - Zeszyty Naukowe Wydziału Zarzadzania i Dowodzenia Akademii Obrony Narodowej nr 4(8), Warszawa, s. 89.

Heywood A.(2007). Ideologie polityczne. Wprowadzenie. Warszawa: PWN.

Kołodziński E.(2008). Wprowadzenie do zarzadzania bezpieczeństwem, Olsztyn: Uniwersytet Warmińsko-Mazurski.

Kuchcik M., Milewski P.(2018). Zanieczyszczenie powietrza w Polsce — stan, przyczyny i skutki, Studia KPZK, tom 182, cz 2, s. 341-364.

Kukułka J.(1995), Ekologiczna koncepcja ładu międzynarodowego w: Stosunki międzynarodowe i polityka. Wyzwania końca stulecia. Księga jubileuszowa na 65-lecie Profesora Bogusława Mrożka, Warszawa.

O programie Czyste powietrze. www.nfosigw.gov.pl/czyste-powietrze/o-programieczyste-powietrze-/ (27.06.2019).

Papuziński A.(2006). Świadomość ekologiczna w świetle teorii i praktyki (Zarys politologicznego modelu świadomości ekologicznej). Problemy Ekorozwoju, 2006, vol1, No. 1, s. 38.

Polityka ekologiczna państwa 2030-projekt, Ministerstwo Środowiska, Warszawa 2019. Pobrano z: www.bip.mos.gov.pl/fileadmin/user_upload/bip/prawo/projekty/PROJEKT_POLITYKI_EKOLOGICZNEJ_PANSTWA_2030/Projekt_Polity ki_ekologicznej_panstwa_2030.pdf (25.06.2019).

Rozporzadzenie Ministra Środowiska z dnia 13 września 2012 r. w sprawie dokonywania oceny poziomów substancji w powietrzu (Dz.U. 2012, poz. 1032)

Skiter N., Rogachev A., Mazaeva T., Modeling Ecological Security of a State , Mediterranean Journal of Social Sciences, Vol 6 No 3, June 2015, s. 185-192.

Strona internetowa projektu Środowisko Życiem: Stop Smog. www.srodowiskozy ciem.pl/ korzysci/ (27.06.2019).

Śladkowski S., (2004). Bezpieczeństwo ekologiczne Rzeczypospolitej Polskiej, Warszawa: AON. 
Taylor G., Viability: A priority criterion for the mitigation of climate change and other complex socio-ecological issues, Journal of Futures Studies, 19(1)/2014, s. $77-96$.

Tollefson, J.,(2020). Climate vs coronavirus: Why massive stimulus plans could represent missed opportunities. Nature 2020. www.nature.com/articles/d41586-02000941-5 (20.06.2020).

Walka o środowisko? Po pandemii możemy wrócić do złych nawyków(2020). www. zdrowie.wprost.pl/koronawirus/w-polsce/10312039/walka-o-srodowisko-po-pandemii-mozemy-wrocic-do-zlych-nawykow.html (19.06.2020).

Xie Y., Hotspots of ecological and environmental risk research in China based on co-word analysis, Journal of Information and Computational Science, 11(4)/2014, s. $1185-1192$.

Yin S.J., Xu P., Chen M., Wu L.H., Consumer's preference on value attributes of ecological food and affecting factor, China Population Resources and Environment, 24(4)2014, s. 71-76.

Zacher L.(1991). Bezpieczeństwo ekologiczne - wymiary polityczne, międzynarodowe $i$ globalne, Lublin: UMCS.

Michal Czuba, PhD, assistant professor, employee of the Institute of Political Science at the Faculty of Social Sciences of the University of Silesia in Katowice. Research interests: functioning of the municipal-utility sector, sustainable development, ecological and social security, ecological policy. 